\title{
EXPERIMENTAL STUDY OF MICRO SILICA BEHAVIOR AND ITS EFFECT ON IRAQI CEMENT PERFORMANCE BY USING
} X-RAY FLUORESCENCE ANALYSIS

\author{
${ }^{1}$ Amel Habeeb Assi" and ${ }^{\mathbf{1}}$ Faleh H. M. Almahdawi \\ Department of Petroleum Engineering, College of Engineering, University of Baghdad, Baghdad, Iraq \\ "E-mail: zahraa_z91@yahoo.com \\ Received: 9 July 2020; accepted: 28 September 2020
}

\begin{abstract}
The cement slurry is a mixture of cement, water and additives which is established at the surface for injecting inside hole. The compressive strength is considered the most important properties of slurry for testing the slurry reliability and is the ability of slurry to resist deformation and formation fluids. Compressive strength is governed by the sort of raw materials that include additives, cement structure, and exposure circumstances. In this work, we use micro silica like pozzolanic materials. Silica fume is very fine noncrystalline substantial. Silica fume can be utilized like material for supplemental cementations for increasing the compressive strength and durability of cement. Silica fume has very fine particles size less than 1 micron and by an average of about 0.1 microns, about 100 times slighter than particles of cement. We are adding 0\%, 5\%, 10\%, 15\%, 20\% and $25 \%$ micro silica by wt. of cement. The results showed that adding micro silica enhance the performance of Iraqi cement but also leads to a slight decrease in thickening time. To avoid this problem, super plasticizer is used to make the process of cement pumping more easily, in other words, increase thickening time and increase compressive strength. The experimental work showed that adding micro silica leads to reduce free water and this property is very important through horizontal drilling. X-ray fluorescence technique delivers beneficial elemental information about the chemical structure of Iraqi cement to help us use it without causing damage through the cementing job. In this paper, some outlines of the XRF device and its main applications are presented. By using X-ray fluorescence analysis, we detect the problem of Iraqi cement and solve it in this paper to use it at cementing jobs in the Iraqi field instead of using imported cement.
\end{abstract}

Keywords: Silica fume; Cement; Compressive strength; Thickening time; XRF 


\section{INTRODUCTION}

Cementing is the technique of making long-lasting cover surroundings the casing for separating it from formations fluids (Dhorgham and Faleh, 2016). An effective cementing careers demands basic aspects should be available: drilling fluid condition, spacers and flushes using, pipe movement, casing centralizing, displacement rate maximizing, slurry design for down hole condition, cement compositions selecting and testing, also an appropriate system selecting of cementing process (Bourgoyne et al.,1986). These properties are usually used for predicting well pore stability (Abdul Majeed and A. AL Haleem, 2020). The finest way for obtaining an appropriate slurry design with preferred compressive strength is by laboratory experiments that include testing various formulations and choosing the finest composition for the particular cementing operation (Al-Jumailya et al., 2015). Cementing is one of the most significant and the most expensive application through drilling process. In cementing job, the annulus between casing and formation is packed with an assured compound of cement and allowed to set, typically next a few hours or a few days, and solidify strongly for joining casing to formation (Bhikshma et al., 2009). That compound could be made from different ingredients with different percentage of weight with respect to the weight of cement in the grout mixture. Cement with a good compressive strength must be capable to resist hard and corrosive formations, lost circulation zone, carbon (IV) oxide and other toxic gas intrusion, and extremely high temperature (Santra et al., 2007; Awadh and Awad 2020). Silica Fume is utilized like material for supplemental cementations for increasing the strength and durability. Silica fume has been known as a pozzolanic material which is active for enhancing the cement properties for a great degree. Its physical composition is: diameter is about 0.1 micron to 0.2 microns; Surface area about $30,000 \mathrm{~m}^{2} / \mathrm{kg}$ and density varies from 150 to $700 \mathrm{~kg} / \mathrm{m}^{3}$. It's too reactive pozzolanic property, which it is used cementing operation because of its fine particles, large surface area and high $\mathrm{SiO}_{2}$ content. Silica fume is much fined parted silica gained as a by-product in manufacturing. It is used as an admixture in the cement combination and it has major effects on the properties of the resultant material (API, 2002). It is very fine having particles size less than 1 micron and with an average diameter of about 0.1 microns, about 100 times smaller than average cement particles.

Silica Fume behavior is related to the high content of amorphous silica $(>90 \%)$. The reduction of high-purity quartz to silicon at temperatures up to $2,000^{\circ} \mathrm{C}$ produces $\mathrm{SiO}_{2}$ vapors, which oxidizes and condense in the low temperature zone to tiny particles consisting of noncrystalline silica. Adding micro silica to slurry creates high strength, durability. When those 
pozzolanic materials are added in slurry then the silica present in these materials react with the calcium hydroxide released during the hydration of cement and forms additional calcium silicate hydrate $(\mathrm{C}-\mathrm{S}-\mathrm{H})$, as a result improve the mechanical properties and durability parameters of concrete (Arina and Sonny, 2010). Researching for any extra material, which can be used as an alternative or to improve slurry properties, may be led to lowermost probable environmental influence. However, if manufacturing by products used as a fractional auxiliary of cement as a consequence of cost saving and substantial energy. Many of pozzolanic material may be used like partly additional or improvement of cement properties for instance are Ground Granulated Blast Furnace Slag, Silica fume or micro silica (Abdullah et al., 2014). X-ray fluorescence (XRF) technique supplies favorable elemental info about the chemical structure of Iraqi cement for facilitating us using it without any damage through cementing job. In this paper, some outline of the XRF device and its main applications are obtainable. The main objective of this research is using silica fume to distinguish the problem of Iraqi cement and resolve it, in other words, enhancing Iraqi cement performance to use it for cementing job in Iraqi oil fields instead of using traditional cement. This material is in general side effect from other productions for example silica fume (Awad and Awadh, 2020). At the moment entire world is opposite a chief problematic of environment pollution, those materials fly ash, micro silica, and others become foremost pollution materials.

\section{MATERIALS AND METHODS}

\section{Micro Silica}

is an amorphous polymorph of silicon dioxide. It is an ultrafine dust calm as a by-product of the silicon and ferrosilicon alloy production and consists of spherical particles with an average particle diameter of 150 Nano meter (Fig. 1a). The chief field request is as pozzolanic material for high cement performance. Silica fume is an ultrafine airborne material with spherical particles less than $1 \mu \mathrm{m}$ in diameter, the ordinary being about $0.1 \mu \mathrm{m}$. That creates it just about 100 times smaller than the average cement particle. The unit weight, or bulk density, of silica fume depends on the metal from which it is produced. Its unit weight usually varies from 130 to $430 \mathrm{~kg} / \mathrm{m}$. The specific gravity of silica fume is generally in the range of 2.20 to 2.5 . To measure the specific surface area of silica fume, a particular experiment named the nitrogen adsorption way should be used. According to that test the specific surface of silica fume typically varieties from 15,000 to $30,000 \mathrm{~m} / \mathrm{kg}$. The micro silica reduces permeability and improves slurry performance. The silica fume responds quickly given that extraordinary early 
strength and durability. The effectiveness of silica fume is 3-5 intervals than OPC (Kong and Ohadi, 2003). Tables 1 displays the physical and chemical properties of micro silica.

Table 1. Physical and chemical properties of micro silica

\begin{tabular}{|c|c|}
\hline Physical properties & Results \\
\hline Physical state & Micronized powder \\
\hline Appearance & White color powder \\
\hline Color & White \\
\hline Pack density & $0.76 \mathrm{gm} / \mathrm{cc}$ \\
\hline pH of 5\% solution & 6.9 \\
\hline Specific gravity & 2.63 \\
\hline Moisture & $0.06 \%$ \\
\hline Oil absorption & $55 \mathrm{ml} / 100 \mathrm{gm}$. \\
\hline Chemical properties & Results \\
\hline Silica $\left(\mathrm{SiO}_{2}\right)$ & $99.89 \%$ \\
\hline Alumina $\left(\mathrm{Al}_{2} \mathrm{O}_{3}\right)$ & $0.04 \%$ \\
\hline Ferric oxide $\left(\mathrm{Fe}_{2} \mathrm{O}_{3}\right)$ & $0.04 \%$ \\
\hline Titanium oxide $\left(\mathrm{TiO}_{2}\right)$ & $0.002 \%$ \\
\hline & \\
\hline
\end{tabular}

\section{Super Plasticizer}

It uses to make the process of cement pumping more easily and we can use it at the following application:

1. Increase cement workability and durability

2. Increase cement compressive and flexural strength

3. Increase elastic modulus

4. Increase adhesion force

5. Reduce permeability, shrinkage, creep and porosity. Slightly increasing in thickening time (Fig. 1b), it is considering high performance for keeping workability and cement mobility, which it is super plasticizer (Bush and Donnell, 2007).

\section{Water}

We use the we use the normal drinking water (Tap Water) to prepare our slurry mixture.

\section{Iraqi Cement}

We use sample for testing from Babel cement plant (Oil well cement, Glass G, HSR) and Omani cement from Rumaila Oilfield (Figs. 1C and 1D).

\section{EXPERIMENTAL AND METHODOLOGY}

\section{Laboratory Experiments}

Are done for obtaining fitting cement slurry properties. These properties are important for getting cement slurry that is proper for horizontal and deviated wells. Some of these properties are as follows: 


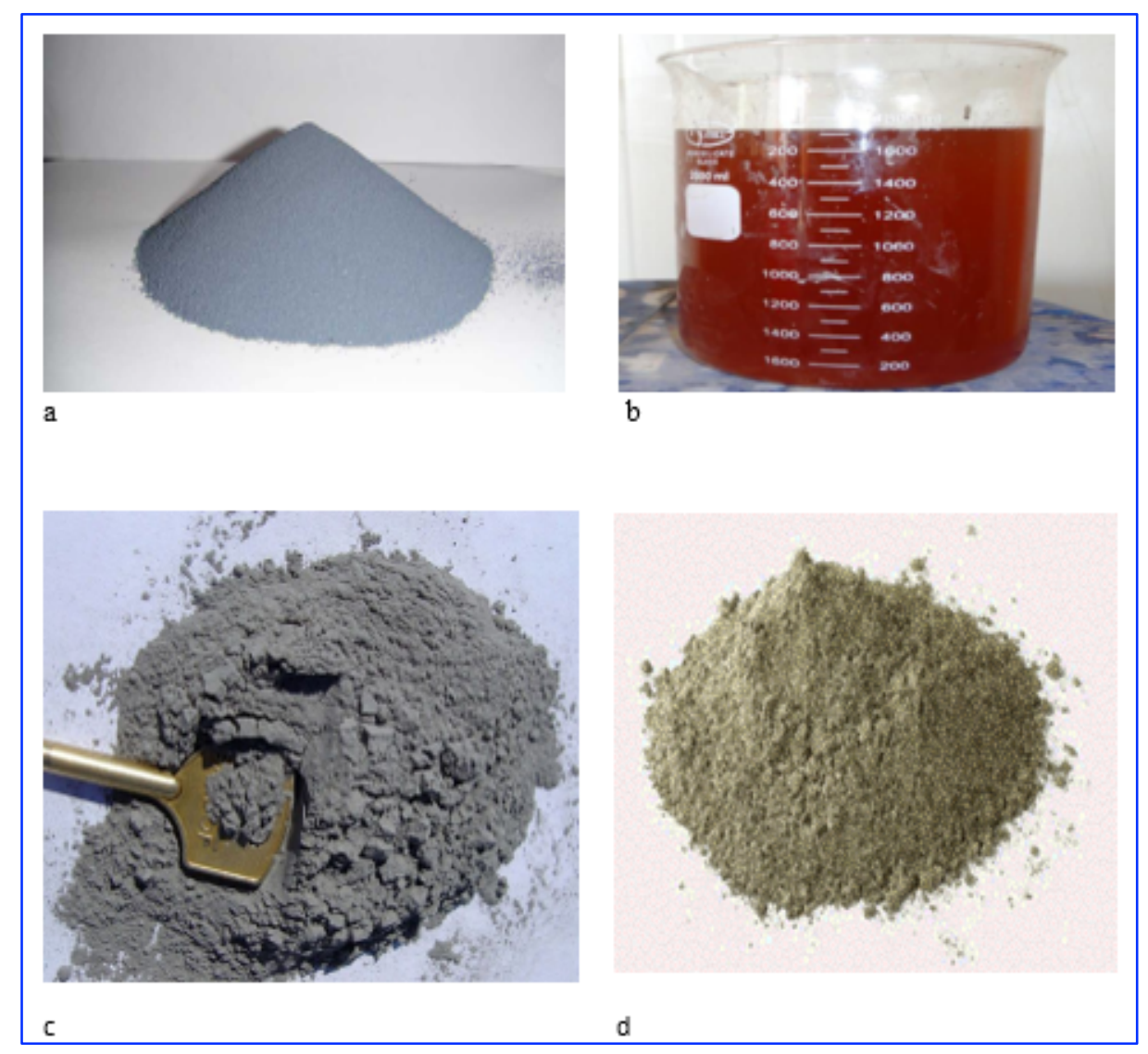

Fig. 1. The used materials which are: (a) Silica fume, (b) Super plasticizer (c) Iraqi cement and (d)Omani cement

\section{Free Water}

OFITE model 60 atmospheric Consistometer is intended to condition cement slurries as indicated within API specification 10A.The free fluid test for testing cement slurries used to cement a well helps determine a slurry's capacity to prevent fluid separation in static conditions, both during placement and after it has been placed into the wellbore. Excessive free fluid in slurry can cause problems with water pockets, channeling, sedimentation, zonal isolation, etc. For the measurement of free water contents, the cement slurry is prepared and conditioned according to API specifications. After the conditioning of cement slurry, the cement is poured in graduated cylinder up to a mark and covered it with aluminum foil to prevent evaporation. Later, it is subjected to 2 hours' test duration. At the end of test duration, a syringe is used to extract the free water separated at the top of cement slurry and the amount of water is measured in milliliters (ml) (Santra et al., 2007).

\section{Thickening Time}

OFITE's model 120 HPHT consistometer was used to measure the thickening time of Iraqi oil well cement under simulated down hole pressure and temperature with and without additives. 
The thickening time indicates the period within which cement slurry remains pump able under well simulated conditions. The laboratory test conditions should represent the time, temperature, and pressure to which cement slurry will be exposed during pumping operations. To determine the thickening time, the consistency of cement slurry is measured. The consistency, expressed in Bearden units of consistency (Bc), is determined by the force imposed by the slurry against the paddle and measured as a torque. A potentiometer, or its equivalent, is used to determine the torque. First the cement slurry is prepared according to API Specifications. The prepared cement slurry is poured in HPHT consist meter cup and placed in HPHT consistmeter. After placing, the test conditions are applied. During the thickening time test, increase the temperature and pressure of the cement slurry in the slurry container in accordance with the appropriate well-simulation test schedule. Then the test is conducted up to the time at which the slurry reaches a consistency deemed sufficient to make it un pumpable (for example $70 \mathrm{Bc}$ or $100 \mathrm{Bc}$ ). The slurry consistency at which the thickening-time test was terminated should be documented and reported. After that, the test is terminated and the consistmeter is cooled before releasing the pressure. After releasing the pressure, the potentiometer and slurry container are removed and prepared for the next test. The acceptance requirement for the maximum consistency during the $15 \mathrm{~min}$ to $30 \mathrm{~min}$ stirring period shall be $30 \mathrm{Bc}$ for all classes of cement manufactured in accordance with this standard (Arina and Sonny, 2010).

\section{Compressive Strength}

The compressive strength properties determine the integrity of cement and its ability to bear long term-imposed stresses. The maximum pressure used for curing is normally 3,000 psi (API), unless otherwise specified. There are two methods to measure the compressive strength, first by crushing and other is by non-destructive method. Compressive strength tests are conducted according to the API specifications. The OFITE model 250 is an automated compressive strength tester that used in this study to determine the compressive strength of well cement by exposing force to the specimen $\left(4 \mathrm{inch}^{2}\right)$ at a continuous rate until the specimen fails. The greatest loading at which the cement specimen is broken is characterized as the cement's compressive strength (Santra et al., 2007)

\section{XRF Analysis}

apparatus for elemental analysis and distribution imaging XRF analysis uses characteristic Xrays (called "fluorescence X-rays") emitted under high-energy X-ray irradiation. XR analysis provides useful elemental information about cement component, is a nondestructive analytical technique used to determine the elemental composition of materials. XRF determine the 
chemistry of sample by measuring the fluorescent X-rays emitted from sample (Strüder et al, 1999) (Table 2).

\section{Rheology Test}

The rheology influences the performance of slurry and assistances in defining the pump ability of the slurry. At rheology test, the flow properties such as: plastic viscosity and yield point of cement slurry are definite, using a rotational viscometer for instance HPHT viscometer by chandler at high temperature conditions. Principally, cement slurry is set and conditioned conferring to API specifications. The conditioned cement is emptied in pre-heated cylinder of viscometer. Rheological parameters gotten by correlation of shear stress in contradiction of shear rate at target temperature. The slurry rheology is tested at different temperatures, could be more than 2 , with the aim of use those data in hydraulic simulators, surface temperature and down hole circulating temperature (Assi, 2020).

\section{Fluid Losses Tests}

This test is performed as per API recommended practice for testing well cements, API does not identify ranges to follow it, but in API 65 they reference that has to be low, $46 \mathrm{ml} / 30 \mathrm{~min}$ is a low value, usually used for production zones (Santra et al., 2007).

\section{Cement Slurry Density}

The density of cement can vary from less than $8.33 \mathrm{ppg}$. for foamed cement to as much as 20 ppg. for densified slurries. Pressurized mud balance is a laboratory testing equipment used for measure cements density. The density of cement slurry is the mass of slurry per the volume of it. It plays an important role in determining the hydrostatic pressure formed by the cement column, as well as in determining the efficiency of displacement by the drilling fluid (Assi, 2020).

\section{Mixer}

Hydraulic mixer is a vital portion of the cement process to develop a homogeneous mix of cement, (Assi, 2020).

Table 2. The chemical composition of Iraqi and Omani cement from XRF Test

\begin{tabular}{|c|c|c|c|}
\hline Component & Iraqi Cement (\%) & Omani Cement (\%) & API standard (\%) \\
\hline $\mathrm{MgO}$ & 1.77 & 0.766 & 0.9 \\
\hline $\mathrm{Al}_{2} \mathrm{O}_{3}$ & 2.996 & 2.428 & 5.6 \\
\hline $\mathrm{SiO}_{2}$ & 18.63 & 37.58 & 24.66 \\
\hline $\mathrm{SO}_{3}$ & 3.072 & 1.846 & 1.55 \\
\hline $\mathrm{CaO}$ & 69.49 & 57.06 & 61.87 \\
\hline $\mathrm{MnO}$ & 0.05061 & 0.0789 & 0.75 \\
\hline $\mathrm{Fe}_{2} \mathrm{O}_{3}$ & 5.587 & 4.964 & 0.38 \\
\hline
\end{tabular}




\section{RESULTS AND DISCUSSION}

Iraqi cement is jelly cement, so it fast thickening time, also it has low compressive strength. If it still in this statement, this type of cement gives bad cementing job because of it low durability. The problem of Iraqi cement is the low percentage of silica which is about $18.63 \%$ depending on XRF analysis. Using micro silica lead to increase the amount of silica which is an important element in cement. It's clear that adding micro silica leads to reduce the amount of free water especially at $25 \%$ micro silica percent (Fig. 2). However, this is very important criteria mainly through horizontal drilling. There are decreasing in the value of thinking time with increasing in the amount of micro silica, it is not acceptable thing (Fig. 3). We used super plasticizer to make the process of cement pumping more easily and give us slightly increasing in thickening time to reach API requirement (Fig. 4) 150x150x150 mm cement cubes were using to find value of compressive strength. Silica fume level was among $0 \%, 5 \%, 10 \%, 15 \%, 20 \%$, and $25 \%$. The compressive strength of cement slurry progresses by accumulative in amount of micro silica (Fig. 5). The perfect rate of micro silica is started at 20\%. Also adding super plasticizer leads to somewhat increasing in compressive strength of cement slurry (Fig. 6). The effect of adding micro silica on the rheological properties, fluid losses and slurry density is presented in Table 3. The values of yield point and plastic viscosity increase with increasing the extent of silica fume, but there are decreasing in the value of fluid losses and density with increasing the silica fume percentage (Table 4). The main compounds of cement which are tricalcium aluminate $\mathrm{C}_{3} \mathrm{~A}$ that hydrates very rabidly and produces most of the heat of hydration observed during the first few days, tetra calcium aluminoferrite $\mathrm{C}_{4} \mathrm{AF}$ that has only minor effects on the physical properties of the cement, tricalcium silicate $\mathrm{C}_{3} \mathrm{~S}$ is thought to be the major contributor to strength, especially during the first 28 days and dicalcium silicate $\mathrm{C}_{2} \mathrm{~S}$ hydrates very slowly and contributes mainly to the long term strength. API uses the following equations (Equation 1to Equation 4): for calculating the weight percent of the cement main components:

$$
\begin{aligned}
& C_{3} S=\left(2.65 * \% \mathrm{Al}_{2} \mathrm{O}_{3}\right)-\left(1.69 * \% \mathrm{Fe}_{2} \mathrm{O}_{3}\right) \\
& C_{4} \mathrm{AF}=3.04 * \% \mathrm{Fe}_{2} \mathrm{O}_{3}
\end{aligned}
$$

When the ratio of $\mathrm{Al}_{2} \mathrm{O}_{3}$ and $\mathrm{Fe}_{2} \mathrm{O}_{3}$ is less than 0.64 , the $\mathrm{C}_{3} \mathrm{~S}$ will be calculated as follows:

$$
\begin{aligned}
& C_{3} S=(4.07 * \% \mathrm{CaO})-\left(7.6 * \% \mathrm{SiO}_{2}\right)-\left(4.48 * \% \mathrm{Al}_{2} \mathrm{O}_{3}\right)-\left(2.86 * \% \mathrm{Fe}_{2} \mathrm{O}_{3}\right)- \\
& \left(2.86 * \% \mathrm{SO}_{3}\right) \\
& \quad C_{2} S=(2.87 * S)-\left(0.754 * C_{3} S\right)
\end{aligned}
$$




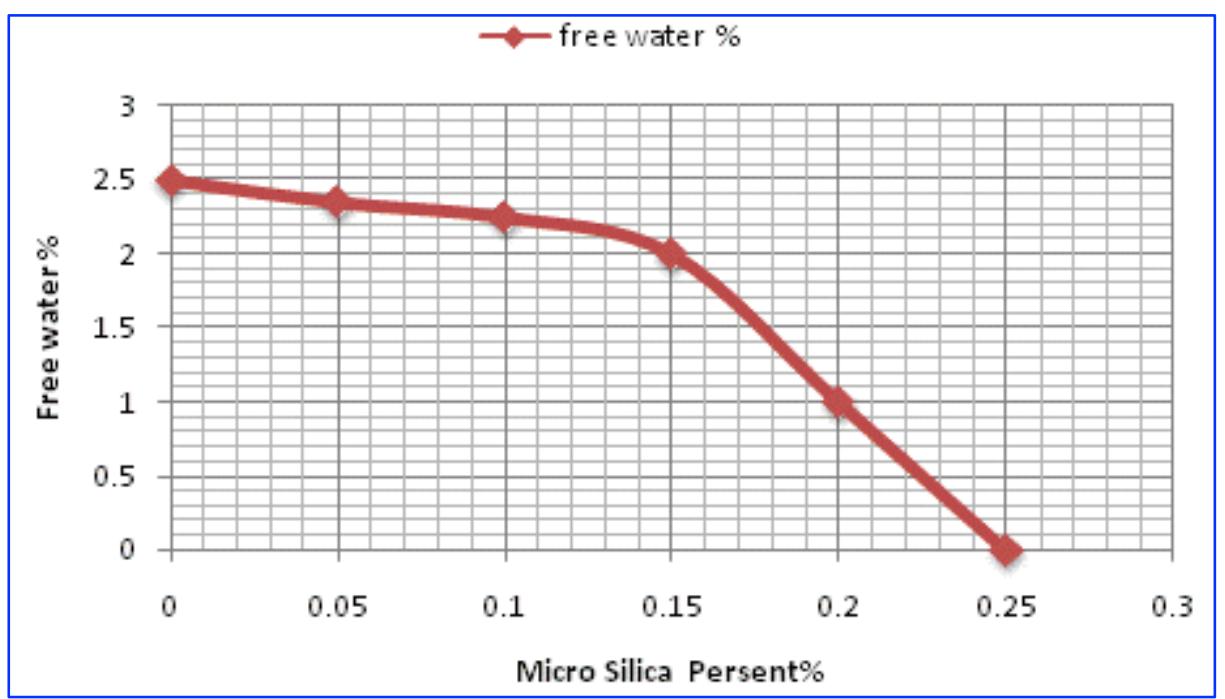

Fig. 2. The effect of micro silica on free water

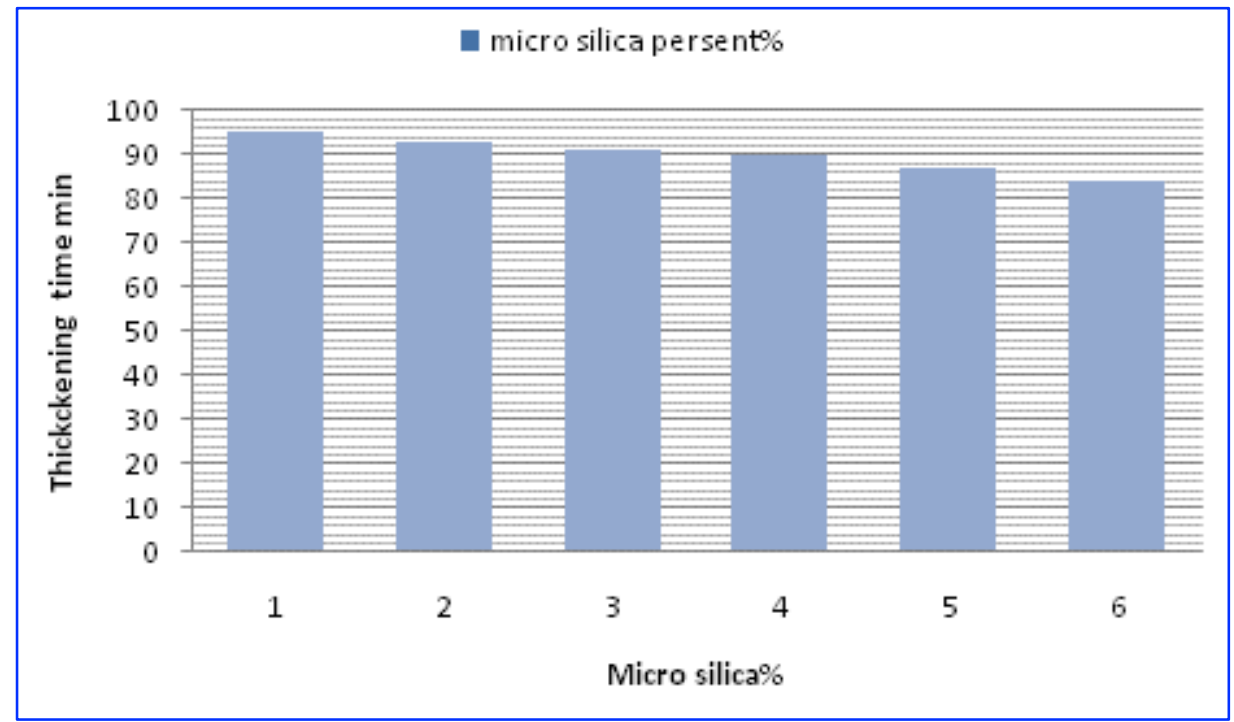

Fig. 3. The effect of micro silica on thickening time

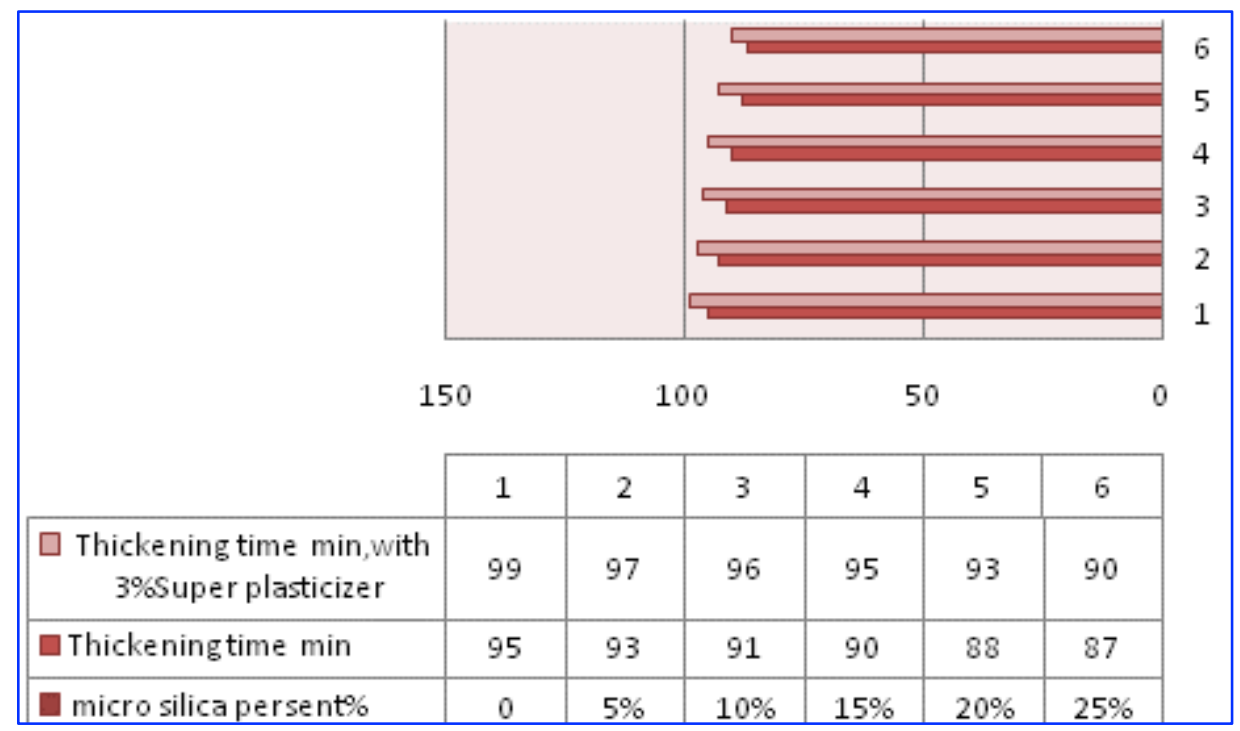

Fig. 4. The effect of super plasticizer on thickening time 


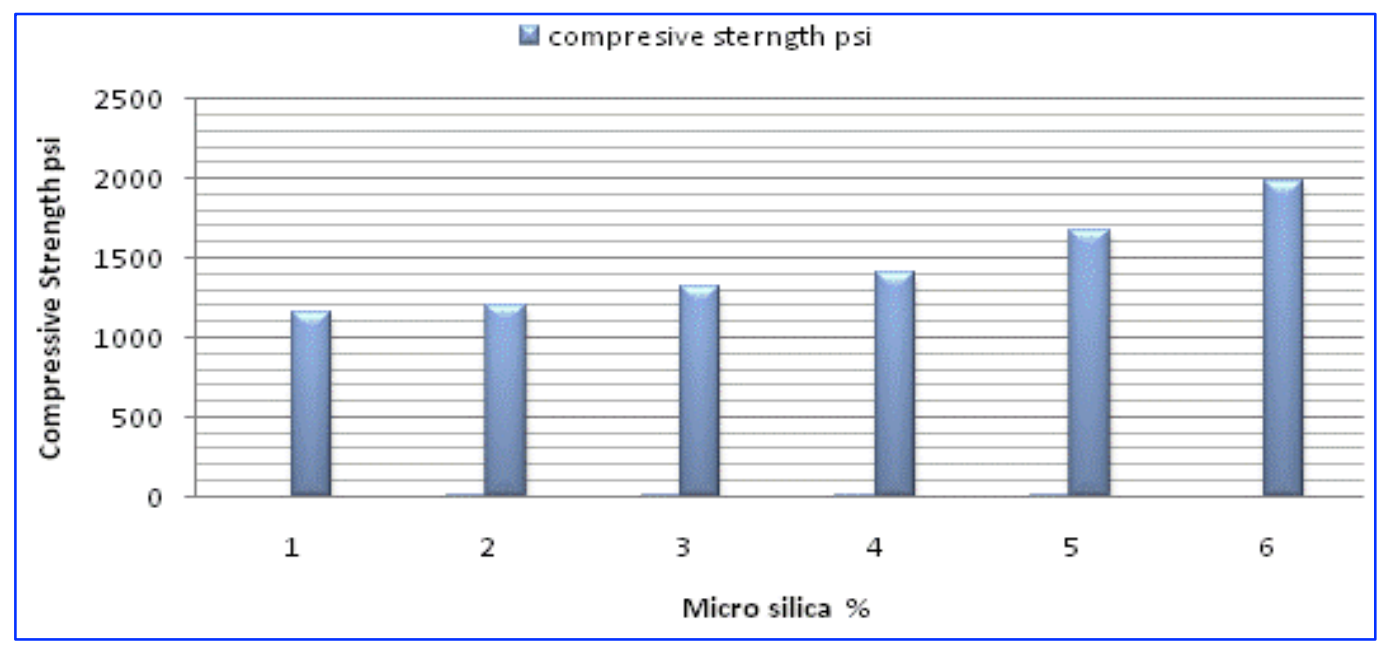

Fig. 5. The effect of micro silica on compressive strength

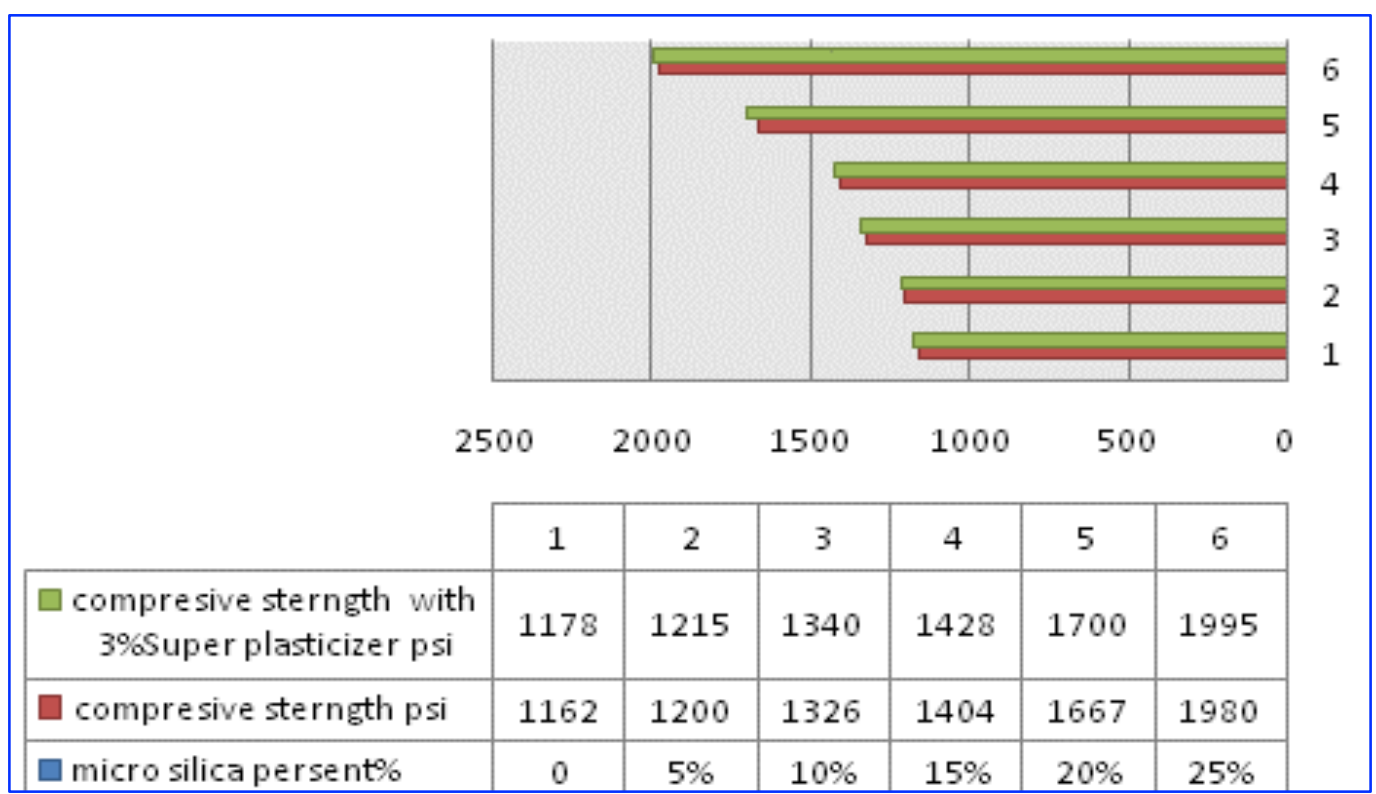

Fig.6. The effect of super plasticizer on compressive strength

Table 3. Result of the cement slurry design at Bottom Hole Circulating Temperature

\begin{tabular}{|c|c|c|c|c|}
\hline Micro silica \% & Plastic viscosity Cp & $\begin{array}{c}\text { Yield point } \\
\text { lb./100ft`2 }^{\wedge}\end{array}$ & $\begin{array}{c}\text { Fluid losses } \\
\text { ml/30 min. }\end{array}$ & $\begin{array}{l}\text { Density } \\
\text { gm/cc }\end{array}$ \\
\hline 0 & 51 & 37 & 42 & 1.88 \\
\hline 5 & 53 & 39 & 40 & 1.87 \\
\hline 10 & 55 & 40 & 39 & 1.86 \\
\hline 15 & 57 & 40 & 36 & 1.85 \\
\hline 20 & 60 & 43 & 30 & 1.84 \\
\hline 25 & 60 & 47 & 25 & 1.8 \\
\hline
\end{tabular}


Table 4. Comparing of chemical composition of Iraqi and Omani cement

\begin{tabular}{|c|c|c|c|c|}
\hline Component & $\begin{array}{c}\text { Iraqi } \\
\text { cement }\end{array}$ & $\begin{array}{c}\text { Iraqi cement after adding } \\
\mathbf{2 0 \%} \text { micro silica }\end{array}$ & $\begin{array}{c}\text { Omani } \\
\text { cement }\end{array}$ & $\begin{array}{c}\text { API } \\
\text { specification }\end{array}$ \\
\hline $\mathrm{C}_{3} \mathrm{~S}$ & 39.82 & 48 & 57.57 & 50 \\
\hline $\mathrm{C}_{2} \mathrm{~S}$ & 19.74 & 20 & 19.31 & 20 \\
\hline $\mathrm{C}_{3} \mathrm{~A}$ & 18.51 & 8.65 & 2.97 & 10 \\
\hline $\mathrm{C}_{4} \mathrm{AF}$ & 14.82 & 10 & 9 & 10 \\
\hline $\mathrm{MgO}$ & 4.34 & 4.38 & 2.42 & 10 \\
\hline
\end{tabular}

\section{CONCLUSIONS}

Established on the search, it is reasonably pure that mineral admixture as silica fume is the most encouraging blending material for providing a good quality cements slurry. The following general conclusions can be drawn based on the mechanical assets of slurry.

1. Silica fume raises the compressive strength of cement slurry; on the other hand, Silica fume is too inexpensive material which its price about $\$ 400$ for one ton until the moment of preparing this paper comparing with cement so it is reasonably priced point of view. The result of tested net cement sample at $60 \mathrm{C}^{\circ}$ is not satisfied compared to the API specification 10A (not exceeded $1500 \mathrm{psi}$ ). This can be attributed to the fact that the high-temperature curing can have a negative impact on early strength development, but after adding micro silica, super plasticizer, Iraqi cement gave high compressive strength.

2. Silica fume is a substantial that lead to air pollution so using of this byproduct of some activities use of micro silica with cement slurry decline the air pollution.

3. Adding silica fume lessens the slurry density and fluid losses, in other words, slightly decrease in the value of slurry density and considerably decrease in the value of fluid losses.

4. Micro silica is reflected an extremely reactive pozzolanic material that offers an enlarged cohesiveness in cement slurry unpaid to its extraordinary fineness modulus. However, the necessity of water may be balanced by adding super plasticizer.

5. The compressive strength of cement slurry growths by increasing in amount of micro silica. The ideal value of micro silica is initiated at $20 \%$.

6. Accumulation of silica fumes lead to reduce free water, and somewhat increasing thickening time of cement slurry and rheological properties.

7. Depending on XRF results, adding $20 \%$ micro silica lead to increase the $\mathrm{C}_{3} \mathrm{~S}$ percentage from $39 \%$ to $48 \%$ and making it nearest to the API standard percentage. 
8. Addition of Super plasticizer (SP) is vital to develop the workability of slurry and increasing thickening time with the attendance of silica fume. The additives levels of SP should be less than $5 \%$ from the used water to slow the setting rate of slurry while keeping the flowing properties of cement slurry.

\section{ACKNOWLEDGMENTS}

The authors are very grateful to the Head of cement section in Petroleum R\&D Center Mr. Qasim Abdulridha Khalti, also the authors are very grateful to engineer Ahmed Abdullah Haiwi from Basra oil company for his supporting, The authors are very grateful to the Editor in Chief Prof. Dr. Salih M. Awadh, the Secretary of Journal Mr. Samir R. Hijab and the Technical Editor Dr. Heba S. Al-Mimar for their great efforts and valuable comments.

\section{REFERENCES}

Assi, A. H., 2020. The effect of some materials on funnel viscosity reading in water base mud. Iraqi Geological Journal, 53(1E): 32-43.

Abdul Majeed, R. K., and ALhaleem, A. A., 2020. Estimation of shear wave velosity from wireline logs data for Amara oilfield, Mishrif Formation,southren Iraq, Iraqi Geological Journal, 53(1A): 36-47.

Arina, B. S., and Sonny, I., 2010. Effects of pressure and temperature on well cement degradation by supercritical $\mathrm{CO}_{2}$. International Journal of Engineerig \& Technology IJET-IJENS,10(4).

Abdullah, A. A., Hamoud, B., Maslehuddin, M., and Al-Amoudi, O., 2014. Effect of silica fume on the mechanical properties of low quality coarse aggregate concrete. Cement and Concrete Composites, 1(26): 891-900.

American Petroleum Institute (API), 2002. Specification 10A: Specification for Cements and Materials for Well Cementing. API/ANSI/ISO 10426-1. Washington, DC:American Petroleum Institute.

Al-Jumailya, I. A. S., Najib, N.; Kareem, Q., 2015. An overview on the Influence of Pozzolanic materials on properties of concrete. International Journal Enhancment Resource Science Technology, 1(4): 81-92.

Awadh, S., M., And Awad, A., M., 2020. Manufacture of Portland cement from Late Miocene claystone, Injana formation, Central Iraq. Arabian Journal of Geosciences, 13, 1008. https://doi.org/10.1007/s12517-020-06032-z.

Awad, A., M., and Awadh, S., M., 2020. Reserve estimation of late Miocene Injana claystone beds for Portland cement and brick industry, middle of Iraq. Iraqi Geological Journal, 53 (1D): 1-16.

Bhikshma,V., Kalidas N., and Venkatesham,Y., 2009 .Investigations on mechanical properties of high strength silica fume concrete. Asian journal of civil engineering building and housing, 10(3):335-346.

Bourgoyne, A.T. Jr., Millheim, K. K., Chenevert, M. E., and Young, F.S., 1986. Applied Drilling Engineering, Society of Petroleum Engineers Text Book Series. Vol.1 :Richardson, TX.

Bush, G., and O'Donnell, K., 2007. Global cementing best practices .Occidental Oil and GasCorp and Global Drilling Community, 65 pp.

Dhorgham, S. I., and Almahdawi, F. H. M., 2016. Addition of super absorbent polymer for upgrading of cement quality in Iraqi Oil wells .Iraqi Journal of Chemical and Petroleum Engineering, 17 (3) :83- 90.

Kong, X., and Ohadi, M., 2003. Silica fume manual: Overview of the recent progress. Society of Petroleum Engineers, 7(12): 55- 64.

Strüder, N. Meidinger, D., Stotter, J. Kemmer, P. Lechner, P. Leutenegger, H. Soltau, F. Eggert, M. Rhode, T. Schülein, 1999. High-resolution X-ray spectroscopy close to room temperature. Microscopy and Microanalysis, 4 (6): 622-631.

Santra, A., Reddy, B. R., \& Antia, M., 2007. Designing cement slurries for preventing formation fluid influx after placement. International Symposium on Oilfield Chemistry held in Houston, Texas, U.S.A., 2(28): 25-37 